\title{
Synthesis, Characterization and Antimicrobial Properties of Some 1,3,4-Thiadiazolines
}

\author{
Houssou Raymond Fatondji ${ }^{1}$, Salomé Kpoviessi ${ }^{1,}$, , Fernand Gbaguidi ${ }^{2}$, Kamirou Chabi Sika ${ }^{4}$, \\ Joachim Gbenou ${ }^{2}$, Georges Coffi Accrombessi ${ }^{1}$, Mansourou Moudachirou ${ }^{2}$, Jacques Poupaert ${ }^{3}$ \\ ${ }^{1}$ Faculty of Sciences and Technics (FAST), University of Abomey-Calavi (UAC), Cotonou, Benin \\ ${ }^{2}$ Beninese Center for Scientific and Technical Research (CBRST), Oganla, Porto-Novo \\ ${ }^{3}$ School of Pharmacy, Université Catholique de Louvain (UCL), Brussels, Belgium \\ ${ }^{4}$ Faculty of Sciences and Technics (FAST), University of Abomey-Calavi (UAC), Abomey, Calavi, Benin
}

Email address:

salome.kpoviessi@fast.uac.bj(S. Kpoviessi)

${ }^{*}$ Corresponding author

\section{To cite this article:}

Houssou Raymond Fatondji, Salomé Kpoviessi, Fernand Gbaguidi, Kamirou Chabi Sika, Joachim Gbenou, Georges Coffi Accrombessi, Mansourou Moudachirou, Jacques Poupaert. Synthesis, Characterization and Antimicrobial Properties of Some 1,3,4-thiadiazolines. American Journal of Applied Chemistry. Vol. 6, No. 2, 2018, pp. 64-70. doi: 10.11648/j.ajac.20180602.15

Received: April 13,2018; Accepted: April 26, 2018; Published: May 18, 2018

\begin{abstract}
Through The literature, there is little information about the antibacterial activity of 1,3,4-thiadiazoles. In order to verify if drugs based on this family of compounds could constitute an alternative to the antibiotics usually used in the antimicrobial fight, the aim of this work was to synthesize, to confirm the structures and then to test some 1,3,4-thiadiazolines for their antimicrobial activity against microbes. Twelve 1,3,4- thiadiazolines were synthesized with yields going from 27 to $95 \%$. The products purity was confirmed by mass spectrometry coupled with high-performance liquid chromatography (LC/MS) and there were characterized using spectrometry IR, NMR ${ }^{1} \mathrm{H}$ and ${ }^{13} \mathrm{C}$ (nuclear magnetic resonance). The synthesized compounds were tested on strains of Escherichia coli ATCC 25922 and Salmonella typhimurium R 30951401 according to the macro-dilution method in liquid environment for a comparison of their antibacterial activity. Thiadiazoline 1 has been shown to be more active than other products. The most antibacterial thiadiazolines are those having para-electro attractor groups and also alkyl groups at R2. It could be a good drug candidate against these microbes.
\end{abstract}

Keywords: 1,3,4-Thiadiazolines, Spectrometric Confirmation, Antimicrobial Properties

\section{Introduction}

Antimicrobial resistance is considered a serious threat to health worldwide $[1,2]$. It is estimated that it is already causing 700,000 deaths each year and, in the absence of effective action, it is expected that it will cause 10 million deaths a year by 2050 . However, humanity has a limited number of effective antibiotics. It is then necessary to broaden the spectrum of antimicrobials and to develop new antibacterial molecules. Thiosemicarbazones have many biological activities such as: antiviral, antifunga $1[5,6]$, antimalarial, antitumor [7-8]. Thiosemicarbazones are also known for their antibacterial properties [9-10]. In addition, thiosemicarbazones are important intermediates in drugs synthesis, formation of metal complexes and heterocycles such as thiadiazolines preparation.

The 1,3,4-thiadiazoles and 1,3,4-thiadiazolines which are cyclic derivatives of the thiosemicarbazones exhibit various biological activities such as antituberculosis antiinflammatory [11], anticonvulsant antihypertensive anticancer and hypoglycemic activities [12]. Therefore, 1, 3, 4-Thiadiazole and related compounds are of great interest in chemistry owing to their bioactivity of certain plant growth regulating effects [13]. The thiosemicarbazones and 1,3,4thiadiazolines thus presented have about the same biological properties however there is little information about the antibacterial activity of 1,3,4-thiadiazolines.

The aim of this work is to synthesize, to confirm the structures by spectrometric methods and then to test the antimicrobial activity of some 1,3,4-thiadiazolines on 
microbes. Its interest lies in the fact that it will make it possible to see if drugs based on 1,3,4-thiadiazolines could constitute an alternative to the antibiotics usually used in the antimicrobial fight.

\section{Material and Methods}

\subsection{Chemistry}

We used thin layer chromatography (TLC) to estimate the purity of the compounds, to follow the evolution of the reaction and then to achieve their purification on silica gel column. The solvent used is the mixture of dichloromethane/ethylacetate $\quad(2 / 1) \quad$ or dichloromethane/methanol (9/1). Compounds purity was confirmed by LC/MS. The melting points were taken on the fusionometer eletrothermal $1 \mathrm{~A} 9000$. The spectrometric data were recorded with the following instruments: IR, Perkin
Elmer FT-IR 286; ${ }^{1} \mathrm{H}$ NMR and ${ }^{13} \mathrm{C}$ NMR, Bruker 400; LC/MS in mode APCI on column C18. The 1,3,4thiadiazolines are synthesized as follows:

1) Synthesis of the thiosemicarbazones. A mixture of ketone $(20 \mathrm{mmol}$ dissolved in $100 \mathrm{~mL}$ of ethanol) and thiosemicarbazide (20 mmol dissolved in $20 \mathrm{ml}$ of $1 \mathrm{~N}$ hydrochloric acid) is stirred until the thiosemicarbazone precipitates. The precipitate is filtered, dried and then recrystallized in ethanol $\left(96^{\circ} \mathrm{C}\right)$ to give thiosemicarbazone crystals (Figure 1).

2) Synthesis of 1,3,4-thiadiazolines. Thiosemicarbazone $(0.25 \mathrm{mmol})$ was dissolved in $0.5 \mathrm{~mL}$ of pyridine and $0.5 \mathrm{ml}$ of acetic anhydride and the mixture was heated at $110^{\circ} \mathrm{C}$ during $3 \mathrm{~h}$ with magnetic stirring to give the 1, 3, 4thiadiazoline derivative which is filtered and purified by flash chromatography (Figure 1).

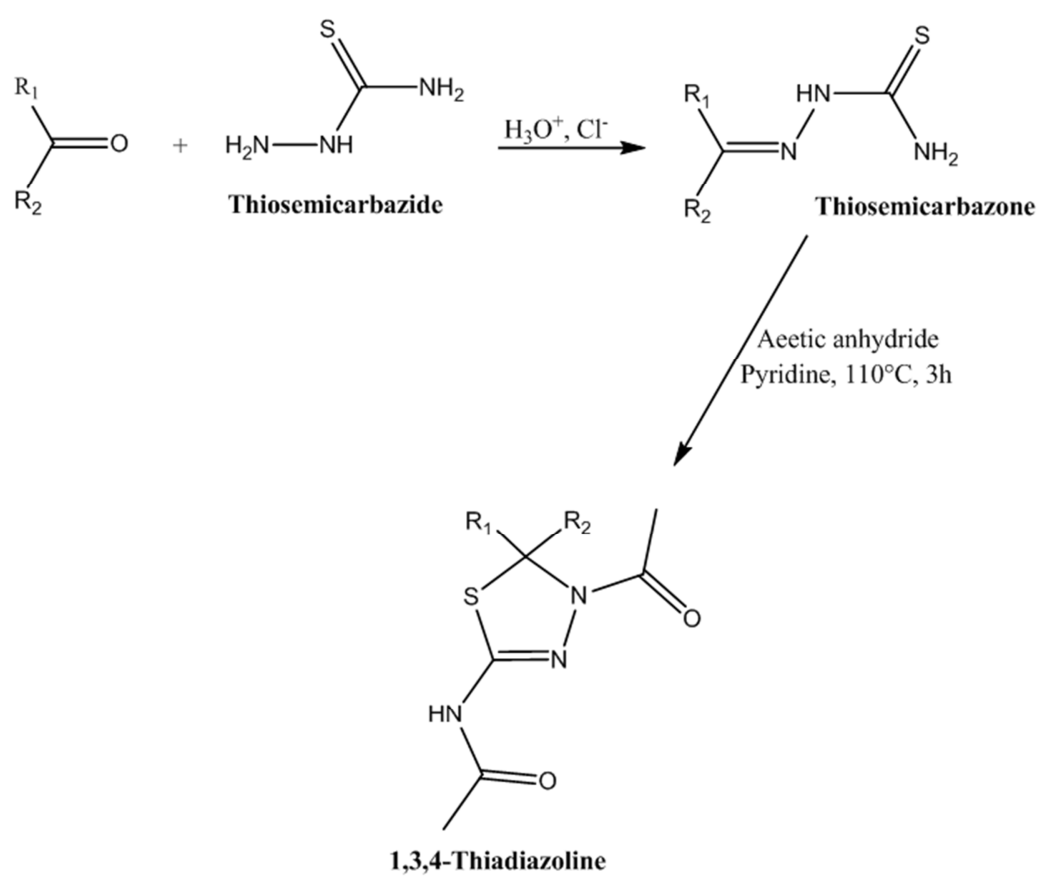

Figure 1. Synthesis of 1,3,4-thiadiazolines (1-12).

\subsection{Antimicrobial Test}

The synthesized compounds were tested on strains of Escherichia coli ATCC 25922 and Salmonella typhimurium $\mathrm{R}$ 30951401. The method used is that of dilution in a liquid medium. The solutions of 1,3,4-thiadiazolines were carried out at an initial concentration of $20 \mathrm{mg} / \mathrm{ml}$ in acetone. The bacterial suspensions were carried out at a colony for $5 \mathrm{ml}$ in LB medium (Luria Bertani) for Escherichia coli and Salmonella typhimurium.

Three series of eight wells initially containing $100 \mu \mathrm{l}$ of distilled water were made. $100 \mu \mathrm{l}$ of solution of $1,3,4-$ thiadiazolines were added to the first well; and a 2-to-2 dilution from one row to another until the eighth set of wells. The microbial suspensions were then added and the wells incubated in an oven at $37^{\circ} \mathrm{C}$.

After 18 hours of incubation, $40 \mu \mathrm{l}$ of a $0.2 \mathrm{mg} / \mathrm{ml}$ solution of p-iodonitrotetrazolium violet (p-INT) are added to each well and the whole is incubated for one hour.

Iodonitrotetrazolium is a reagent for the detection of enzymatic activity. In the medium, it is reduced by mitochondrial enzymes and stains red; thus marking the presence of life and enzymatic activity in the environment. Wells stained red are those in which the concentration of synthetic products is insufficient to inhibit bacterial growth. The MIC corresponds to the concentration of the undyed well in which there is the lowest amount of 1,3,4-thiadiazolines. The reading is done in comparison with the control wells. It should also be noted that a series of positive controls has been performed with equivalent concentrations of gentamycin. 


\section{Results and Discussions}

\subsection{Chemistry}

Twelve 1, 3, 4- thiadiazolines were synthesized with yields going from 27 to $95 \%$. The physical and spectrometric data of the 12 compounds are reported in Table 1. Thin layer chromatography (TLC) shows that 1,3,4-thiadiazolines have Rf up 0.37 to 0.77 .

Table 1. Chemical structure, yield, and melting point of synthesized 1,3,4-thiadiazolines (1-12).

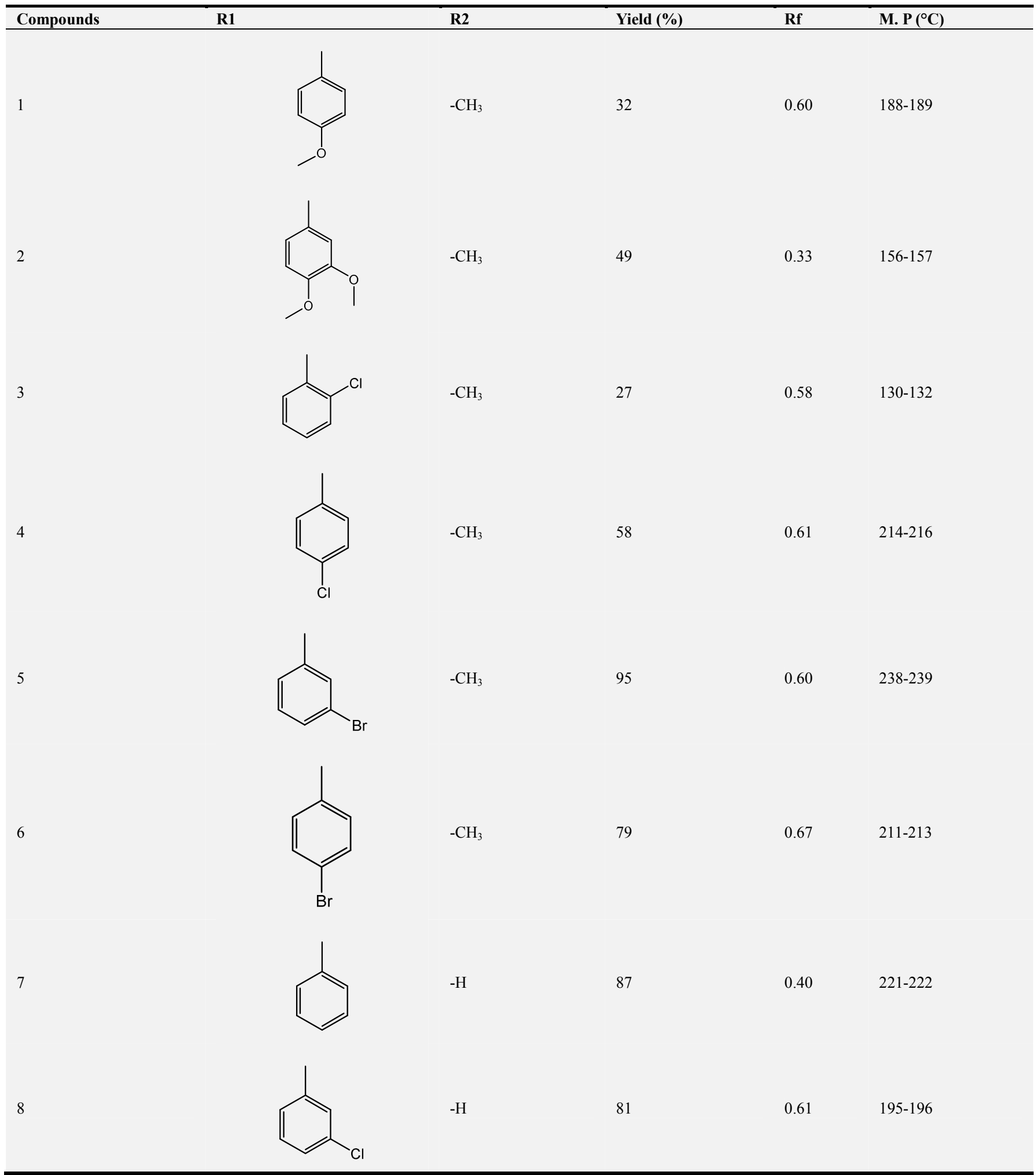




\begin{tabular}{|c|c|c|c|c|c|}
\hline Compounds & R1 & R2 & Yield (\%) & Rf & M. P $\left({ }^{\circ} \mathbf{C}\right)$ \\
\hline 9 & & $-\mathrm{H}$ & 77 & 0.77 & $228-230$ \\
\hline 10 & & $-\mathrm{CH}_{2}-\mathrm{CH}_{3}$ & 66 & 0.60 & $209-210$ \\
\hline 11 & & $-\mathrm{H}$ & 70 & 0.56 & $210-211$ \\
\hline 12 & & $-\mathrm{H}$ & 94 & 0.37 & $245-246$ \\
\hline
\end{tabular}

The spectrometric data of this table are in conformity with the structures suggested for the products.

Thus the IR spectra of 1,3,4-thiadiazolines show bands in the range of $3146-3232 \mathrm{~cm}^{-1}$ due to the stretching vibration of NH.

The NH group is also demonstrated in ${ }^{1} \mathrm{H}$ NMR through its hydrogen which has chemical shifts of between 9.10 and $11.90 \mathrm{ppm}$ for the twelve 1,3,4-thiadiazolines synthesized.

In ${ }^{13} \mathrm{C}$ NMR spectra, ring closure in 1,3,4-thiadiazolines may be observed by (1) the disappearance of the signal between 177 and 179 corresponding to the thiocarbonyl group, (2) the appearance of a signal between 63 and $81 \mathrm{ppm}$ assigned to C-2 and (3) the signals of the carbonyl and methyl moieties of the acetyl groups incorporated to the molecule.

In mass spectrometry, the $[\mathrm{MH}]^{+}$peaks obtained in APCI mode correspond to molecular weights expected for all products. In LC mode, all 1,3,4-thiadiazolines have a single peak confirming their purity.

The details concerning the spectral data are listed in the appendix. The synthesized compounds were tested for their antibacterial activity on Escherichia coli ATCC 25922 and Salmonella typhimurium R 30951401.

\subsection{Microbiology}

The antimicrobial test results of the twelve 1,3,4thiadiazolines synthesized are shown in Table 2 below. Following the analysis of this result, we find that 1,3,4thiadiazolines are more active on Salmonella typhimurium than on Escherichia coli. 1, 3, 4-thiadiazoline 1 is the most active of all with a MIC of $0.625 \mathrm{mg} / \mathrm{mL}$ on Salmonella typhimurium. 1,3,4-thiadiazolines 11, 6 and 5 are the least active on Salmonella typhimurium. The para-methoxy group on 1, 3, 4-thiadiazoline 1 seems to play an important role in inhibiting the growth of Salmonella typhimurium because its replacement with a chlorine or bromine atom in compounds 4 and 6 is reflected by a gradual loss of activity. It also finds a decrease in activity when an additional methoxy group is added in the meta position at compound 2 level.

Table 2. Minimal inhibitory concentration (MIC) of synthesized compounds.

\begin{tabular}{lll}
\hline \multirow{2}{*}{ Compounds } & MIC $(\mathbf{m g} / \mathbf{m L})$ & \\
\cline { 2 - 3 } & Escherichia coli & Salmonella typhimurium \\
\hline 1 & $>10$ & 0.625 \\
2 & $>10$ & 10 \\
3 & $>10$ & 10 \\
4 & 5 & 2.5 \\
5 & $>10$ & $>10$ \\
6 & $>10$ & $>10$ \\
7 & 10 & 2.5 \\
8 & $>10$ & 10 \\
9 & $>10$ & 10 \\
10 & 1.25 & 5 \\
11 & $>10$ & $>10$ \\
12 & 5 & 5 \\
\hline
\end{tabular}

The presence of the methyl group in $\mathrm{R} 2$ of the thiadiazolines is also important for the inhibition of the growth of Salmonella typhimurium because, its replacement by a hydrogen atom in the compound 4 leads to the compound 9 thus causing an increase in the MIC which goes from $5 \mathrm{mg} / \mathrm{mL}$ to more than $10 \mathrm{mg} / \mathrm{mL}$. There is also a decrease in inhibitory activity when in thiadiazoline 1 which 
has a MIC of $0.625 \mathrm{mg} / \mathrm{ml}$ is replaced by methyl in $\mathrm{R} 2$ by an ethyl group; a MIC of $5 \mathrm{mg} / \mathrm{mL}$ is increased with thiadiazoline 10 .

The 1,3,4-thiadiazolines synthesized are not very active on Escherichia coli. However, the best MIC is $1.25 \mathrm{mg} / \mathrm{mL}$ for compound 10 . The trend observed for the structure-activity relationship of thiadiazolines in Salmonella typhimurium appears to be the same with Escherichia coli with a few exceptions. Indeed, in the case of compound 10, the presence of the ethyl group in R2 instead of the methyl group is rather beneficial for the inhibition of the growth of Escherichia coli.

\section{Conclusion}

From this work which consisted in highlighting the antibacterial activity of certain 1,3,4-thiadiazolines on Salmonella typhimurium and Escherichia coli, it appears that the antibacterial potency of thiadiadiazolines varies according to the microbial strains. The synthesized compounds seem more active against Salmonella typhimurium than Escherichia coli. Among the twelve tested compounds, N-(4-acetyl-5-ethyl-5-(4-methoxyphenyl)-4, 5dihydro-1, 3, 4-thiadiazol-2-yl)acetamide (10) was the most active against Escherichia coli with MIC $<1.5 \mathrm{mg} / \mathrm{mL}$ and $\mathrm{N}$-(4-acetyl-5-(4-methoxyphenyl)-5-methyl-4, 5-dihydro1,3,4-thiadiazol-2-yl)acetamide (1), the most active against Salmonella typhimurium with MIC $<0.7 \mathrm{mg} / \mathrm{mL}$. The most antibacterial thiadiazolines are those that have paraelectroattractor groups and also alkyl groups at R2. They could be good drug candidates against these microbes.

\section{Appendix}

Spectral data of 1,3,4-thiadiazolines (1-12)

N-(4-acetyl-5-(4-methoxyphenyl)-5-methyl-4, 5-dihydro-1, 3, 4-thiadiazol-2-yl) acetamide (1):

LC/MS: $[\mathrm{MH}]^{+}$calculated: 308, $1063[\mathrm{MH}]^{+}$found: 308, 1059.

IR m $\left(\mathrm{KBr} \mathrm{cm}^{-1}\right): 3171(\mathrm{NH}) ; 1691,1643$ and $1614(\mathrm{C}=\mathrm{O}$ amides).

${ }^{1} \mathrm{H}$ NMR d $\left(\mathrm{CDCl}_{3} \mathrm{ppm}\right): 1,88\left(3 \mathrm{H}, \mathrm{s}, \mathrm{CH}_{3}\right) ; 2,19(3 \mathrm{H}, \mathrm{s}$, $\mathrm{CH}_{3}$ amide); 2, 27 (3H, s, $\mathrm{CH}_{3}$ amide); 3, 34 (3H, s, O- $\mathrm{CH}_{3}$ ); 6, 75-7, 27 (4H, several signals, ArH); 9, 13 (1H, s, NH).

${ }^{13} \mathrm{C} \mathrm{NMR} \mathrm{d}\left(\mathrm{CDCl}_{3} \mathrm{ppm}\right): 22,87\left(\mathrm{CH}_{3}\right) ; 23,89$ and 26,86 (2. $\mathrm{CH}_{3}$ amides); 55, $29\left(\mathrm{O}-\mathrm{CH}_{3}\right) 80,03$ (C2 of the ring); 124, 99-142, 82 (Aromatic C); 143, $48(\mathrm{C}=\mathrm{N}) ; 168,84$ and 169, $27(\mathrm{C}=\mathrm{O}$ amides $)$.

N-(4-acetyl-5-(3, 4-dimethoxyphenyl)-5-methyl-4, 5dihydro-1, 3, 4-thiadiazol-2-yl) acetamide (2):

LC/MS: $[\mathrm{MH}]^{+}$calculated: 338, $1169[\mathrm{MH}]^{+}$found: 338 , 1165 .

IR m $\left(\mathrm{KBr} \mathrm{cm}^{-1}\right): 3169(\mathrm{NH}) ; 1698,1646$ and $1601(\mathrm{C}=\mathrm{O}$ amides).

${ }^{1} \mathrm{H}$ NMR d $\left(\mathrm{CDCl}_{3} \mathrm{ppm}\right): 1,80\left(3 \mathrm{H}, \mathrm{s}, \mathrm{CH}_{3}\right) ; 2,23(3 \mathrm{H}, \mathrm{s}$, $\mathrm{CH}_{3}$ amide); 2, 25 (3H, s, $\mathrm{CH}_{3}$ amide); 3, $78\left(3 \mathrm{H}, \mathrm{s}, \mathrm{O}-\mathrm{CH}_{3}\right)$; 3, $79\left(3 \mathrm{H}, \mathrm{s}, \mathrm{O}-\mathrm{CH}_{3}\right) ; 6,68-6,91(3 \mathrm{H}$, several signals, $\mathrm{ArH})$; 9, $94(1 \mathrm{H}, \mathrm{s}, \mathrm{NH})$.
${ }^{13} \mathrm{C} \mathrm{NMR} \mathrm{d}\left(\mathrm{CDCl}_{3} \mathrm{ppm}\right): 22,64\left(\mathrm{CH}_{3}\right) ; 23,86$ et 26,68 (2. $\mathrm{CH}_{3}$ amides); 55, $91\left(\mathrm{O}-\mathrm{CH}_{3}\right) ; 56,91\left(\mathrm{O}-\mathrm{CH}_{3}\right)$ 79, $72(\mathrm{C} 2$ of the ring); 109, 14-135, 17 and 148, 83; 148, 90 (Aromatic $\mathrm{C}$ ); $144,22(\mathrm{C}=\mathrm{N}) ; 169,33$ and $169,34(\mathrm{C}=\mathrm{O}$ amides $)$.

$\mathrm{N}$-(4-acetyl-5-(2-chlorophenyl)-5-methyl-4, 5-dihydro-1, 3, 4-thiadiazol-2-yl) acetamide (3)

LC/MS: $[\mathrm{MH}]^{+}$calculated: 312,$0568 ;[\mathrm{MH}]^{+}$found: 312 , 0565 .

IR m $\left(\mathrm{KBr} \mathrm{cm}^{-1}\right): 3160(\mathrm{NH}) ; 1698,1644$ et $1611(\mathrm{C}=\mathrm{O}$ amides).

${ }^{1} \mathrm{H}$ NMR d $\left(\mathrm{CDCl}_{3} \mathrm{ppm}\right): 1,86\left(3 \mathrm{H}, \mathrm{s}, \mathrm{CH}_{3}\right) ; 2,26(3 \mathrm{H}, \mathrm{s}$, $\mathrm{CH}_{3}$ amide); 2, 36 (3H, s, $\mathrm{CH}_{3}$ amide) 7, 19-7, 42 (4H, several signals, $\mathrm{ArH}) ; 9,61(1 \mathrm{H}, \mathrm{s}, \mathrm{NH})$.

${ }^{13} \mathrm{C}$ NMR d $\left(\mathrm{CDCl}_{3} \mathrm{ppm}\right): 28,85 \mathrm{CH}_{3} ; 22,96$ et 23,01 (2. $\mathrm{CH}_{3}$ amides); 78, 35 (C2 of the ring); 126, 64-137, 27 (C Aromatic); 144, $37(\mathrm{C}=\mathrm{N}) ; 168,68$ and 169, $78(\mathrm{C}=\mathrm{O}$ amides).

$\mathrm{N}-(4-a c e t y l-5-(4-c h l o r o p h e n y l)-5-m e t h y l-4$, 5-dihydro-1, 3, 4-thiadiazol-2-yl) acetamide (4)

LC/MS: $[\mathrm{MH}]^{+}$calculated: 312,$0568 ;[\mathrm{MH}]^{+}$found: 312 , 0567.

IR m (KBr cm$\left.{ }^{-1}\right): 3146(\mathrm{NH}) ; 1694,1633$ et $1617(\mathrm{C}=\mathrm{O}$ amides)

${ }^{1} \mathrm{H}$ NMR d $\left(\mathrm{CDCl}_{3} \mathrm{ppm}\right): 1,75\left(3 \mathrm{H}, \mathrm{s}, \mathrm{CH}_{3}\right) ; 2,22(3 \mathrm{H}, \mathrm{s}$, $\mathrm{CH}_{3}$ amide); 2, 24 (3H, s, $\mathrm{CH}_{3}$ amide) 7, 19-7, 27 (4H, several signals, ArH); 10, $14(1 \mathrm{H}, \mathrm{s}, \mathrm{NH})$.

${ }^{13} \mathrm{C} \mathrm{NMR} \mathrm{d}\left(\mathrm{CDCl}_{3} \mathrm{ppm}\right): 22,49\left(\mathrm{CH}_{3}\right) ; 23,78$ et 26,62 (2. $\mathrm{CH}_{3}$ amides); 78, 90 (C2 of the ring); 126, 68-141, 31 (C Aromatic); 144, $86(\mathrm{C}=\mathrm{N}) ; 169,40$ and 169, $56(\mathrm{C}=\mathrm{O}$ amides).

$\mathrm{N}$-(4-acetyl-5-(3-bromophenyl)-5-methyl-4, 5-dihydro-1, 3, 4-thiadiazol-2-yl) acetamide (5)

LC/MS: $[\mathrm{MH}]^{+}$calculated: 357,$0102 ;[\mathrm{MH}]^{+}$found: 357 , 097.

IR m $\left(\mathrm{KBr} \mathrm{cm}{ }^{-1}\right): 3218,3146 \vee(\mathrm{NH}) ; 1694,1614(\mathrm{C}=\mathrm{O}$ amides).

${ }^{1} \mathrm{H}$ NMR d (DMSO-d ${ }_{6}$ ppm): 2, $03\left(3 \mathrm{H}, \mathrm{s}, \mathrm{CH}_{3}\right) ; 2,20(3 \mathrm{H}$, s, $\mathrm{CH}_{3}$ amide); 2, 27 (3H, s, $\mathrm{CH}_{3}$ amide) 7, 32-7, 59 (4H, several signals, ArH); 11, $69(1 \mathrm{H}, \mathrm{s}, \mathrm{NH})$.

${ }^{13} \mathrm{C}$ NMR d (DMSO-d $\left.)_{6}\right): 22,40\left(\mathrm{CH}_{3}\right) ; 23,58$ et 26,30 (2. $\mathrm{CH}_{3}$ amides); 77, 86 (C2 of the ring); 121, 72-142, 30 (C Aromatic); 146, $84(\mathrm{C}=\mathrm{N}) ; 167,77$ and 169, $45(\mathrm{C}=\mathrm{O}$ amides).

$\mathrm{N}$-(4-acetyl-5-(4-bromophenyl)-5-methyl-4, 5-dihydro-1, 3, 4-thiadiazol-2-yl) acetamide (6)

LC/MS: $[\mathrm{MH}]^{+}$calculated: 358,$0048 ;[\mathrm{MH}]^{+}$found: 358 , 0042 .

IR m $\left(\mathrm{KBr} \mathrm{cm}{ }^{-1}\right): 3217,3148(\mathrm{NH}) ; 1695,1614(\mathrm{C}=\mathrm{O}$ amides).

${ }^{1} \mathrm{H}$ NMR d $\left(\mathrm{CDCl}_{3} \mathrm{ppm}\right): 1,75\left(3 \mathrm{H}, \mathrm{s}, \mathrm{CH}_{3}\right) ; 2,22(3 \mathrm{H}, \mathrm{s}$, $\mathrm{CH}_{3}$ amide); 2, 24 (3H, s, $\mathrm{CH}_{3}$ amide); 7, 21-7, 37 (4H, several signals, $\mathrm{ArH}) ; 10,32(1 \mathrm{H}, \mathrm{s}, \mathrm{NH})$.

${ }^{13} \mathrm{C} \mathrm{NMR} \mathrm{d}\left(\mathrm{CDCl}_{3} \mathrm{ppm}\right): 22,54\left(\mathrm{CH}_{3}\right) ; 23,85$ et 26,59 (2. $\mathrm{CH}_{3}$ amides); 78, 95 (C2 of the ring); 121, 93-141, 85 (C Aromatic); 144, $34(\mathrm{C}=\mathrm{N}) ; 169,39$ and 169, $55(\mathrm{C}=\mathrm{O}$ amides).

N-(4-acetyl-5-phenyl-4, 5-dihydro-1, 3, 4-thiadiazol-2-yl) 
acetamide (7):

LC/MS: $[\mathrm{MH}]^{+}$calculated: 264,$0801 ; \quad[\mathrm{MH}]^{+}$found: 264,0796.

IR m $\left(\mathrm{KBr} \mathrm{cm}^{-1}\right): 3216,3165(\mathrm{NH}) ; 1713,1702,1634$ ( $\mathrm{C}=\mathrm{O}$ amides $)$.

${ }^{1} \mathrm{H}$ NMR d (DMSO-d 6 ppm): 2, 04 (3H, s, $\mathrm{CH}_{3}$ amide); 2, 21 (3H, s, $\mathrm{CH}_{3}$ amide); 6, $84(1 \mathrm{H}, \mathrm{s}, \mathrm{CH}) ; 7,24-7,37(5 \mathrm{H}$, several signals, $\mathrm{ArH}) ; 11,76(1 \mathrm{H}, \mathrm{s}, \mathrm{NH})$.

${ }^{13} \mathrm{C}$ NMR $\mathrm{d}\left(\mathrm{DMSO}_{6}\right): 21,85$ and $22,52\left(2 . \mathrm{CH}_{3}\right.$ amides); 65, 79 (C2 of the ring); 125, 04-141, 37 (Aromatic C); 145, $97(\mathrm{C}=\mathrm{N})$; 167, 27 and 167, $39(\mathrm{C}=\mathrm{O}$ amides $)$.

N-(4-acetyl-5-(3-chlorophenyl)-4, 5-dihydro-1, 3, 4thiadiazol-2-yl) acetamide (8)

LC/MS: $\left[\mathrm{MH}^{+}\right.$calculated: 298,0411; $[\mathrm{MH}]^{+}$found: 298,0410 .

IR m ( $\left.\mathrm{KBr} \mathrm{cm}^{-1}\right)$ : $3208(\mathrm{NH}) ; 1663$ et $1625(\mathrm{C}=\mathrm{O}$ amides $)$.

${ }^{1} \mathrm{H}$ NMR d (DMSO-d 6 ppm): 2, 04 (3H, s, $\mathrm{CH}_{3}$ amide); 2, $22\left(3 \mathrm{H}, \mathrm{s}, \mathrm{CH}_{3}\right.$ amide); 7, 21-7, $42(5 \mathrm{H}$, several signals, $4 \mathrm{H}$ ArH and $\left.1 \mathrm{H} \mathrm{CH}_{2}\right) ; 11,80(1 \mathrm{H}, \mathrm{s}, \mathrm{NH})$.

${ }^{13} \mathrm{C}$ NMR d (DMSO-d 6 ): 21, 81 et 22,52 (2. CH3 amides); 65, 08 (C2 du cycle); 123, 76-143, 74 (C Aromatic); 145, 94 $(\mathrm{C}=\mathrm{N}) ; 167,53$ et $169,50(\mathrm{C}=\mathrm{O}$ amides $)$.

N-(4-acetyl-5-(4-chlorophenyl)-4， 5-dihydro-1, 3, 4thiadiazol-2-yl) acetamide (9):

LC/MS: $\quad[\mathrm{MH}]^{+}$calculated: 298,$0412 ; \quad[\mathrm{MH}]^{+}$found: $294,0407$.

IR m $\left(\mathrm{KBr} \mathrm{cm}{ }^{-1}\right): 3216,3163(\mathrm{NH}) ; 1698,1637,1612$ $(\mathrm{C}=\mathrm{O}$ amides $)$.

${ }^{1} \mathrm{H}$ NMR d (DMSO-d 6 ppm): 2, 04 (3H, s, $\mathrm{CH}_{3}$ amide); 2, $20\left(3 \mathrm{H}, \mathrm{s}, \mathrm{CH}_{3}\right.$ amide); 6, $83\left(1 \mathrm{H}, \mathrm{s}, \mathrm{CH}_{2}\right) ; 7,28-7,42(4 \mathrm{H}$, several signals, ArH); 11, $78(1 \mathrm{H}, \mathrm{s}, \mathrm{NH})$.

${ }^{13} \mathrm{C}$ NMR d $\left(\right.$ DMSO-d $\left._{6}\right): 21,83$ and 22, 51 (2. $\mathrm{CH}_{3}$ amides); 65, 15 (C2 of the ring); 127, 13-140, 28 (Aromatic C); 145, $88(\mathrm{C}=\mathrm{N}) ; 167,44$ and 169, $44(\mathrm{C}=\mathrm{O}$ amides $)$.

$\mathrm{N}$-(4-acetyl-5-ethyl-5-(4-methoxyphenyl)-4, 5-dihydro-1, 3, 4-thiadiazol-2-yl)acetamide (10):

LC/MS: $\quad[\mathrm{MH}]^{+}$calculated: 322,$1225 ; \quad[\mathrm{MH}]^{+}$found: 322,1217 .

IR m (KBr cm $\left.{ }^{-1}\right): 3227,3177(\mathrm{NH}) ; 1697,1643$ and 1610 ( $\mathrm{C}=\mathrm{O}$ amides $)$.

${ }^{1} \mathrm{H}$ NMR d $\left(\mathrm{CDCl}_{3} \mathrm{ppm}\right): 1,06\left(3 \mathrm{H}, \mathrm{t}, \mathrm{CH}_{3}\right) ; 2,18(2 \mathrm{H}, \mathrm{q}$, $\left.\mathrm{CH}_{2}\right) ; 2,23$ ( $3 \mathrm{H}, \mathrm{s}, \mathrm{CH}_{3}$ amide); 2,26 ( $3 \mathrm{H}, \mathrm{s}, \mathrm{CH}_{3}$ amide); $3,67\left(3 \mathrm{H}, \mathrm{s}, \mathrm{O}-\mathrm{CH}_{3}\right) ; 7,73-7,25(4 \mathrm{H}$, several signals, $\mathrm{ArH})$; $9,84(1 \mathrm{H}, \mathrm{s}, \mathrm{NH})$.

${ }^{13} \mathrm{C} \mathrm{NMR} \mathrm{d}\left(\mathrm{CDCl}_{3}\right): 9,91\left(\mathrm{CH}_{3}-\mathrm{CH}_{2}-\right) ; 22,61$ and 23,80 (2. $\mathrm{CH}_{3}$ amides); 29, $95\left(\mathrm{CH}_{3}-\mathrm{CH}_{2}-\right) ; 55,29\left(\mathrm{O}-\mathrm{CH}_{3}\right) ; 84,85$ $\left(\mathrm{C}_{2}\right.$ of the ring); 113,82-135,89 and 159,07 (Aromatic $\mathrm{C}$ ); $144,17(\mathrm{C}=\mathrm{N}) ; 169,28$ and $169,43(\mathrm{C}=\mathrm{O}$ amides $)$.

N-(4-acetyl-5-(p-tolyl)-4, 5-dihydro-1, 3, 4-thiadiazol-2yl)acetamide (11)

LC/MS: $[\mathrm{MH}]^{+}$calculated: 278,$0958 ;[\mathrm{MH}]^{+}$found: 278,0953 .

IR m $\left(\mathrm{KBr} \mathrm{cm}^{-1}\right): 3215,3164(\mathrm{NH}) ; 1698$ et $1636(\mathrm{C}=\mathrm{O}$ amides).

${ }^{1} \mathrm{H}$ NMR d $\left(\mathrm{CDCl}_{3} \mathrm{ppm}\right): 1,98\left(3 \mathrm{H}, \mathrm{s}, \mathrm{Ar}-\mathrm{CH}_{3}\right) ; 2,20(3 \mathrm{H}$, $\mathrm{s}, \mathrm{CH}_{3}$ amide); 2, $23\left(3 \mathrm{H}, \mathrm{s}, \mathrm{CH}_{3}\right.$ amide); 6, $71\left(1 \mathrm{H}, \mathrm{s}, \mathrm{CH}_{2}\right)$; 7, 02-7, 10 (4H, several signals, ArH); 9, 42 (1H, s, NH).
${ }^{13} \mathrm{C} \mathrm{NMR} \mathrm{d}\left(\mathrm{CDCl}_{3} \mathrm{ppm}\right): 21,16\left(\mathrm{CH}_{3}\right) ; 22,14$ et 23,01 (2. $\mathrm{CH}_{3}$ amides); 67, 51 (C2 of the ring); 125, 65-138, 63 (C Aromatic); 146,80 $(\mathrm{C}=\mathrm{N}) ; 168,91$ and $169,11(\mathrm{C}=\mathrm{O}$ amides $)$.

N-(4-acetyl-5-(2-nitrophenyl)-4， 5-dihydro-1， 3, 4thiadiazol-2-yl)acetamide (12):

LC/MS: $\quad[\mathrm{MH}]^{+}$calculated: 309,$0652 ; \quad[\mathrm{MH}]^{+}$found: 309,064

IR m (KBr cm $\left.{ }^{-1}\right): 3232,3192(\mathrm{NH}) ; 1682,1664$ and 1622 ( $\mathrm{C}=\mathrm{O}$ amides $)$.

${ }^{1} \mathrm{H}$ NMR d (DMSO-d 6 ppm): 2, 04 (3H, s, $\mathrm{CH}_{3}$ amide); 2, $26\left(3 \mathrm{H}, \mathrm{s}, \mathrm{CH}_{3}\right.$ amide $) ; 7,06\left(1 \mathrm{H}, \mathrm{s}, \mathrm{CH}_{2}\right) ; 7,33-8,18(4 \mathrm{H}$, several signals, $\mathrm{ArH}) ; 11,86(1 \mathrm{H}, \mathrm{s}, \mathrm{NH})$.

${ }^{13} \mathrm{C}$ NMR d (DMSO-d 6$): 21,70$ and 22, 41 (2. $\mathrm{CH}_{3}$ amides); 63, 15 (C2 of the ring); 125, 52-145, 01 (Aromatic C); 146, $31(\mathrm{C}=\mathrm{N}) ; 167,77$ et $169,66(\mathrm{C}=\mathrm{O}$ amides $)$.

\section{References}

[1] Laxminarayan R, Duse A, Wattal C, Zaidi AK, Wertheim HF, Sumpradit N, et al. Antibiotic resistance - the need for global solutions. Lancet Infect Dis. 2013 Dec; 13(12):105798.http://dx.doi.org/10.1016/S1473-3099(13)70318-9pmid: 24252483

[2] Antibiotic resistance coalition. Declaration on antibiotic resistance [Internet]. 2014.

[3] Review on antimicrobial resistance. Tackling drug-resistant infections globally [Internet]. London: Wellcome Trust; 2014. Available from: http://amr-review.org [cited 2015 Jan 13].

[4] Garcia CC, Brousse BN, Carlucci MJ, Moglioni AG, Martins AM, Moltrasio GY, D'Accorso NB, Damonte EB. Inhibitory effect of thiosemicarbazone derivatives on Junin virus replication in vitro. Antivir Chem Chemother 2003; 14:99 105.

[5] Kovač T, Kovač M, Strelec I, Nevistić A, Molnar M (2017) "Antifungal and antiaflatoxigenic activities of coumarinyl thiosemicarbazides against Aspergillus flavus NRRL 3251» DOI: 10.1515/aiht-2017-68-2883

[6] De Araújo Neto LN, do Carmo Alves de Lima M, de Oliveira JF, de Souza ER, Buonafina MDS, Victor Anjos MN, Brayner FA, Alves LC, Neves RP, Mendonça-Jnior FJB (2017) «Synthesis, cytotoxicity and antifungal activity of 5-nitrothiophene-thiosemicarbazones derivatives» Chem Biol Interact. Jun 25; 272: 172-181. DOI: 10.1016/j.cbi.2017.05.005.

[7] Afrasiabi Z, Sinn E, Padhye S, Dutta S, Newton C, Anson CE, Powell AK. Transition metal complexes of phenanthrenequinone thiosemicarbazone as potential anticancer agents: synthesis, structure, spectroscopy, electrochemistry and in vitro anticancer activity against human breast cancer cell-line T47D. J Inorg Biochem 2003; 95(4):306-314.

[8] Afrasiabi Z, Sinn E, Chen JN, Ma YF, Rheingold AL, Zakharov LN, Rath N, Padhye S. Appended 1, 2naphthoquinones as anticancer agents 1: synthesis, structural, spectral and antitumor activities of ortho-naphthoquinone thiosemicarbazone and its transition metal complexes. Inorg Chim Acta 2004; 357(1):271-278. 
[9] Sau DK, Butcher RJ, Chandhuri S, Saha N (2003) Spectroscopic, structural and antibacterial properties of copper (II) complexes with bio-relevant 5-methyl-3-formylpyrazole $\mathrm{N}$ (4)-benzyl-N (4) methylthiosemicarbazone. Mol Cell Biochem $2003 ; 253(1-2): 21-22$.

[10] Rebolledo AP, de Lima GM, Gambi LN, Speziali NL, Maia DF, Pinheiro CB, Ardisson JD, Cortes ME, Beraldo Hl (2003) Tin (IV) complexes of 2-benzoylpyridine $\mathrm{N}$ (4)phenylthiosemicarbazone: spectral characterization, structural studies and antifungal activity. Appl Organomet Chem 2003; 17: 945 .

[11] Labanauskas L, Kalcas V, Udrenaite E, Gaidelis P, Brukstus A, Dauksas V (2001). Synthesis of 3-(3, 4-dimethoxyphenyl)-
$1 \mathrm{H}-1,2,4$ - triazole-5-thiol et 2-amino-5-(3, 4dimethoxyphenyl)-1, 3, 4-thiadiazole derivatives exhibiting anti-inflammatory activity. Pharmazie., 56: 617.

[12] Chou JY, Lai SY, Pan SL, Chern JW, Guh JH (2003). Investigation ofanticancer mechanism of thiadiazole-based compound in human non-small cell lung cancer A549 cells. Biochem. Pharmacol, 66: 115.

[13] Sancak K, Unver Y, Er M (2007). Synthesis of 2-a, 2aroylamino et ethoxycarbonyl imino-1,3,4-thiadiazolines as antitumor agents. Turk. J. Chem., 31: 125. 